TEACHING TACTIC

\title{
The Buddha's Positionality
}

\author{
Christina A. Kilby \\ James Madison University
}

\section{The context}

I teach at a public research university in rural Virginia with a student population that is increasing in diversity. I assign this thirty to forty-five minute teaching tactic near the beginning of an undergraduate "Introduction to Buddhism" course. This tactic works best in classes sized for discussion; my classes consist of twenty-five to thirty students. Although this example uses the life of the Buddha, the exercise can be easily adapted to focus on another historical figure.

\section{The pedagogical purpose}

To prompt students to reflect critically on their own positionalities ${ }^{1}$ in the religious studies classroom as well as to culturally and historically contextualize the life of a human figure they are studying. This exercise serves as an entry into self-reflective scholarship, providing a model for speaking academically about identity and difference for students who may have little experience doing so.

\section{Description of the strategy}

I first ask students to write down the various positionalities or social locations that impact how they as individuals engage with the study of religion: class, creed, gender, sexuality, race, language, and so forth. Then, students complete the same positionality exercise about the Buddha. Drawing closely from a narrative or film depiction of the Buddha's life story (such as BBC's 2005 Life of the Buddha ${ }^{2}$ ) that I have assigned, they glean which positionalities mattered in the Buddha's time and place for his religious quest: human being (not god), prince, warrior caste, wealthy, male, straight, father, ancient person, Indian, able-bodied, renunciate. When I next ask students to review their own positionalities in light of their role as scholars encountering the Buddha, they discover additional positionalities in themselves: twenty-first-century person, westerner (perhaps), citizen of a democracy (perhaps), consumer, English speaker, non-renunciate, user of modern learning technologies, and so forth. We reflect on these discoveries as a group in order to explore the cross-cultural and cross-historical nature of religious studies.

\section{Why it is effective}

Students enjoy exercises in self-reflection upon their identity, but such reflections are rarely situated in dialogue with the academic content they are studying. By comparing their own positionalities with the Buddha's, students practice contextualizing themselves, contextualizing the Buddha, and identifying some of the cultural and historical distances across which their study of the Buddha's life and teachings occurs.
1 https://www.dictionary.com/e/gender-sexuality/positionality/.

2 https://www.youtube.com/watch?v=kEe8hl6GoGY (accessed 14 August 2019). 